\title{
Acute Hepatitis Following the Use of a Slimming Pill Containing Herbal Elements
}

\author{
Herbal Elemanlar Içeren Zayıflama Hapı Kullanımı \\ Sonrası Gelişen Akut Hepatit
}

Olgu Sunumu Case Report

Received/Geliş: 07.01.2020 Accepted/Kabul: 04.05.2020 Published Online: 18.08.2021

Damla Çağla Patır Sağlık Bilimleri Üniversitesi, Izmir Tepecik SAUM, iç Hastalıkları Kliniği, Izmir - Türkiye damlapatir@yahoo.com ORCID: 0000-0002-3376-2525

H. Akar 0000-0002-0936-8691 Sağlık Bilimleri Üniversitesi, izmir Tepecik SAUM, iç Hastalıkları Kliniği, İmir - Türkiye

Cite as: Patır DÇ, Akar H. Acute hepatitis following the use of a slimming pill containing herbal elements. Tepecik Eğit. ve Arașt. Hast. Dergisi. 2021;31(2):272-4.

\author{
Damla Çağla Patır ${ }^{\oplus}$, Harun Akar ${ }^{\circledR}$
}

ABSTRACT

Toxic hepatitis can be seen in a wide spectrum from mild biochemical abnormalities to acute liver failure. Today, rates of access to herbal products for weight loss have increased. In this article, we present a case of toxic hepatitis associated with the use of herbal slimming pills.

Keywords: Toxic hepatitis, obesity, Garcinia Cambogia

ÖZ

Toksik hepatit, hafif biyokimyasal anormallikten akut karaciğer yetmezliğine kadar geniş bir spektrumda karşımıza çıkabilir. Günümüzde, kilo verme amaciyla herbal ürünlere ulasim oranlari artmıştır. Bu yazıda bitkisel içerikli zayıflama hapı kullanımı ile toksik hepatit birlikteliği olan bir olgu sunulmaktadır.

Anahtar kelimeler: Toksik hepatit, obezite, Garcinia Cambogia

\section{INTRODUCTION}

Acute hepatitis is a clinical condition characterized by liver cell necrosis and inflammation and may develop due to various causes such as viruses, drugs, alcohol, metabolic diseases and toxins. Many infectious conditions such as brucellosis, salmonellosis, tuberculosis, hydatid cysts can also be considered as non-viral acute hepatitis etiologies. Ischemic hepatitis and autoimmune hepatitis are among the causes of acute hepatitis (1). On the other hand, liver damage caused by drugs and herbal substances is one of the leading causes of toxic hepatitis (2). Although the importance of obesity-related mortality and morbidity has been known for a long time, nowadays it grows like a snowball and has reached serious dimensions that threaten public health. On the other hand, it is thought that different herbal medicines called slimming pills are widely used without the supervision of a physician ${ }^{(2)}$. There are limited publications on the side effects of these herbal products which contain many active biological substances ${ }^{(3)}$.

\section{CASE}

A 47-year-old female patient was admitted to the emergency department with the complaints of nausea and vomiting and abdominal pain that started the day before. The patient's

(C) Telif hakkı TC. Să̆lık Bakanlı̆̆ı izmir Tepecik Eğit. ve Arastt. Hastanesi. Logos Tip Yayıncılık tarafindan yayınlanmaktadır. Bu dergide yayınlanan bütün makaleler Creative Commons Atff-GayriTicari 4.0 Uluslararası Lisansı ile lisanslanmıştı.

(c) Copyright Association of Publication of the T.C. Ministry of Health Izmir Tepecik Education and Research Hospital.

This journal published by Logos Medical Publishing.

Licenced by Creative Commons Attribution-NonCommercial 4.0 International (CC BY) 
history revealed that she was using herbal medicine for slimming. She have been using Garcinia Cambogia containing pills (totally 13 tablets) which included fruit peel extract, safflower oil, gelatin, carob scale, green tea extract, guarana seed, caffeine, thyme powder, garlic slimming oil, prickly figs and bean seeds for 20 days for slimming purposes. The patient stated that she was using slimming pills 3 times a day before meals. Physical examination was normal except for tendernessn on the epigastric region and increased bowel sounds. Laboratory examinations were as follows: WBC: 5200/ $\mathrm{mm}^{3}$, $\mathrm{Hgb}: 13.3 \mathrm{~g} / \mathrm{dl}$, PLT: 265,000/mm³, ALT: 912 U/L, AST: 964 U/L, ALP: $212 \mathrm{U} / \mathrm{L}$ and LDH: $372 \mathrm{U} / \mathrm{L}$, total bilirubin: $3.59 \mathrm{mg} /$ dl, direct bilirubin: $2.18 \mathrm{mg} / \mathrm{dl}, \mathrm{HBsAg}(-)$, AntiHBs (-), AntiHAV IgM (-), AntiHAV IgG (-), AntiHCV (-), AntiHIV $(-)$, Gruber-Widal test, Wright test, Anti-CMV IgM, AntiToxo IgM, AntiRubella IgM, EBV VCA IgM, ANA, $A M A$ and Anti-SM were negative. Other laboratory values were within normal limits. In ultrasonography, the liver was normal in size and the parenchymal structure was homogeneous; liver parenchymal echogenicity was consistent with grade 1 hepatosteatosis. With the diagnosis of acute toxic hepatitis, herbal medicines were discontinued and symptomatic treatment was given. One week later, the patient's clinical and laboratory findings improved, and she was discharged with cure, with recommendations not to use slimming pills. The patient did not have any complaints at the follow-up visits.

\section{DISCUSSION}

In general, the potential side effects and safety of herbal products are not routinely and precisely investigated before their use, unlike prescription drugs that are strictly controlled by the FDA and similar organizations. Herbal supplements; may cause liver damage by inducing P450 gene transcription, inhibiting P450 enzyme activity, or creating toxic compounds after hepatic metabolism without affecting P450 gene level and enzyme activity ${ }^{(4,5)}$. Garcinia cambogia extract and herbal products containing Garcinia cambogia are among the popular dietary supplements marketed mainly for slimming purposes ${ }^{(6)}$. In experimental studies, GC has been reported to protect against high-fat dietinduced obesity by modulating adipose fatty acid synthesis and $\beta$-oxidation, but causing hepatic fibrosis, inflammation and oxidative stress ${ }^{(7)}$. YoungJe Kim and colleagues showed that the Garcinia Cambogia (GC) supplementation reduced expression and activity of fatty acid synthase mRNA, while peroxisome proliferator-activated receptor $\alpha$ (PPAR $\alpha)$ and carnitine palmitoyltransferase (CPT) mRNA expression along with the activities of CPT and $\beta$-oxidation were increased in the visceral adipose tissue, and plasma resistin level were decreased experimentally, so they suggested that these changes may be potential mechanisms for reducing body fat deposition and glucose intolerance induced by highfat diet (HFD). However, Young-Je Kim and colleagues also demontstrated that GC increased proinflammatory monocyte chemoattractant protein-1 (MCP-1) and tumor necrosis factor- $\alpha$ (TNF- $\alpha$ ) mRNA expressions, lipid peroxidation and collagen deposition in the liver tissue. The increase in plasma alanine aminotransferase (ALT) and aspartate aminotransferase (AST) levels with GC supplementation in HFD-induced obese mice suggested that GC might contribute to hepatic fibrosis, inflammation and oxidative stress ${ }^{(7)}$. YoungJe Kim and colleagues lightened us by displaying that the GC supplementation partly contributes to the development of steatohepatitis by increasing collagen deposition, lipid peroxidation, MCP-1 and TNF- $\alpha$ mRNA expressions and plasma AST and ALT levels in the liver in HFD-induced obese mice. Lunsford et al. reported a case of fulminant liver failure associated with Garcinia Cambogia supplementation for the first time ${ }^{(6)}$. One active ingredient in this dietary supplement is hydroxycitric acid which is banned by the USA Food and Drug Administration in 2009 for its hepatotoxicity, and this active ingredient is also found in weight-loss supplements ${ }^{(6)}$. We believe that our awareness of the potential complications of dietary supplements such as Garcinia cambogia should be increased in order to prevent the possibility of hepatotoxicity and 
potential fulminant liver failure. As in our case, we believe that in the event of deterioration in liver function tests using Garcinia Cambogia (GC) supplementation, the possibility of toxic hepatitis should be kept in mind and these drugs should be discontinued immediately in appropriate clinical situations.

Conflict of Interest: There is no conflict of interest related to any person and/or institution.

Informed Consent: Informed consent was taken from the patient.

\section{REFERENCES}

1. Tabak F. Akut Hepatitler. I..Ü. Cerrahpaşa Tıp Fakültesi Sürekli Tıp Eğitimi Etkinlikleri Hepato-Bilier Sistem ve Pankreas
Hastalıkları Sempozyum Dizisi 2002;28:43-55.

2. Devarbhavi $\mathrm{H}$, Bonkovsky $\mathrm{HL}$, Russo $\mathrm{M}$ et al. Drug-Induced Liver Injury. In: Zakim and Boyer's Hepatology: A Textbook of Liver Disease . Seventh Edition. Elsevier: Philadelphia; 2018. P 844-890. [CrossRef]

3. Teschke, R, Eickhoff, A. Herbal hepatotoxicity in traditional and modern medicine: Actual key issues and new encouraging steps. Front. Pharmacol. 2015;6:1-40. [CrossRef]

4. Tucker GT, Houston JB, Huang SM İlaç geliştirmeyi optimize etme: Bir fikir birliğine doğru ilaç metabolizması/taşıyıcı etkileşimi potansiyelini değerlendirme stratejileri. Clin. Pharmacol. Ther. 2001;70:103-14.

5. Teschke R, Wolff A, Frenzel C, Schulze J, Eickhoff A. Herbal hepatotoxicity: A tabular compilation of reported cases. Liver Int. 2012;32:1543-1556. [CrossRef]

66. Lunsford KE, Bodzin AS1, Reino DC, Wang HL, Busuttil RW. Dangerous dietary supplements: Garcinia cambogiaassociated hepatic failure requiring transplantation. World J Gastroenterol. 2016;22(45):10071-6. [CrossRef]

7. Kim YJ, Choi MS, Park YB, Kim SR, Lee MK, Jung UJ. Garcinia Cambogia attenuates diet-induced adiposity but exacerbates hepatic collagen accumulation and inflammation. World J Gastroenterol. 2013;19(29):4689-701. [CrossRef] 